\title{
A COMPUTATIONAL STUDY ON A SERIES OF PHENANTHRENE AND PHENANTHROLINE BASED POTENTIAL ORGANIC PHOTOVOLTAICS
}

\author{
Ayşegül Gümüş, Selçuk Gümüş* \\ Department of Chemistry, Faculty of Science, Van Yuzuncu Yil University, 65080, Van, Turkey \\ gumuss@gmail.com
}

\begin{abstract}
A series of phenanthrene and phenanthroline derivatives were considered computationally by the application of Density Functional Theory at the B3LYP/6-31++G(d,p) level to investigate their potential usage as organic solar cell components, thermally activated delayed fluorescence and nonlinear optic compounds. The structures were constructed as a D- $\pi$-A motif in order to increase the ability to achieve intramolecular charge transfer enabling them to act as organic semiconductors. The inter-frontier energy gap of all compounds was found to be in the range of semiconductors. The thermally activated delayed fluorescence (TADF) properties of the compounds were also discussed in relation to the results obtained by TD-DFT calculations. Some of them possessed very narrow triplet-singlet transition energy leading to future TADF applications. Moreover, the nonlinear optic characteristics of all compounds were investigated through calculations of the total molecular dipole moment $\left(\mu_{\mathrm{tot}}\right)$, linear polarizability $\left(\alpha_{\mathrm{tot}}\right)$ and hyperpolarizability $\left(\beta_{\mathrm{tot}}\right)$. The results indicate the potential nonlinear optic property of all of the systems.
\end{abstract}

Keywords: phenanthrene; phenanthroline; TADF; organic solar cells; NLO

\section{ПРЕСМЕТКОВНО ИСТРАЖУВАҢЕ НА СЕРИЈА ПОТЕНЦИЈАЛНИ ОРГАНСКИ ФОТОВОЛТАИЦИ БАЗИРАНИ НА ФЕНАНТРЕН И ФЕНАТРОЛИН}

Серија деривати на фенантрен и фенатролин беа теориски разгледувани со примена на теоријата на густината на фунцкионалот на ниво на B3LYP/6-31++G(d,p) за да се испита нивната потенцијална употреба како органски компоненти на соларни ќлии, термички активирана одложена флуоресценција и нелинеарни оптички соединенија. Структурите беа разгледувани како $\mathrm{D}-\pi-\mathrm{A}$ мотив со цел да се зголеми способноста да се постигне интрамолекулски пренос на полнеж, што ќе овозможи да се однесуваат како органски полуспроводници. Својствата на термички активираната одолжена флуоресценција (TADF) на соединенијата се дискутирани во однос на резултатите добиени со пресметки со TD-DFT. Некои од нив имаат многу блиска транзициска енергија на триплет-синглет преминот, што овозможува нивна идна примена за TADF. Исто така, беа испитани нелинеарните оптички карактеристики на сите соединенија преку пресметка на вкупниот молекулски диполен момент $\left(\mu_{\mathrm{tot}}\right)$, линеарната поларизаблиност $\left(\alpha_{\mathrm{tot}}\right)$ и хиперполаризабилноста $\left(\beta_{\mathrm{tot}}\right)$. Резултатите укажуваат на потенцијални нелинеарни оптички својства на сите испитани системи.

Клучни зборови: фенатрен; фенантролин; TADF; органски соларни ќелии; NLO

\section{INTRODUCTION}

The amount of energy that the sun produces is enormous, such that the Earth receives enough energy to fulfill the yearly world demand in less than an hour, although not all of that energy reaches the Earth's surface due to absorption and scattering [1]. The continuous supply of energy from the sun introduces the photovoltaic conversion of solar energy as an important challenge. Solar cells 
of inorganic materials have a recorded energy conversion efficiency of around $39 \%$ [2], whereas commercially available solar panel systems have a significantly lower efficiency range of between 15 and $20 \%$.

The solar energy industry is seeking both high power conversion efficiency and low cost materials. However, the prices of silicon-based solar cell power plants or solar energy panels are still not competitive with other traditional combustion rivals. The use of organic materials can serve as an alternative approach to lowering the manufacturing costs of solar cells, which can be processed under less demanding conditions. The research for novel organic photovoltaics has been continued for more than 30 years; however, within the last decade, developments in the field have gained considerable momentum [3, 4]. Organic solar cells bring the advantages of mechanical flexibility, ease of processing, and low cost of production. Moreover, chemical modification is easy for the customization of desired properties. However, the energy conversion efficiency for these organics still needs to be improved, since a maximum efficiency of only $4-5 \%$ has been reached to date [5].

The architectures of organic solar cells are based on two kinds of materials: electron donors (D) and electron acceptors (A), respectively. Organic compounds which possess donor-acceptor units exhibit important optical and photophysical characteristics [6]. Donor-acceptor compounds are widely used in molecular electronics applications, and it is of interest to investigate how their properties can be manipulated and probed. The $\pi$ electronic characteristics of molecular donor (D) acceptor (A) compounds have been attracting attention in solid state science as well as for their potential technological development in organic electronics. The DA solar cells apply the photoinduced electron transfer [7] to separate the electron from the hole. The photo-induced electron transfer takes place from the excited state of the donor to the LUMO of the acceptor.

In order to gain higher efficiencies for organic solar cells, the primary strategy can be adjusting the highest occupied molecular orbital (HOMO) and the lowest unoccupied molecular orbital (LUMO) energy levels by chemical tailoring. This strategy is rather useful since the difference between HOMO and LUMO determines the light absorption regions [8], the open-circuit voltage $\left(\mathrm{V}_{\mathrm{oc}}\right)$ heavily depends on the gap of $\mathrm{LUMO}_{\mathrm{ac}}$ ceptor $-\mathrm{HOMO}_{\text {donor }}[9]$ and sufficient $\Delta \varepsilon$ (the difference between HOMOs or LUMOs of donor and acceptor), which usually needs to be at least 0.3
$\mathrm{eV}$, is necessary for excitons dissociation at the donor-acceptor interface [10]. Recently, two methods have been used to modify the energy levels of potential molecules: 1) to establish a donoracceptor (D-A) conjugated backbone by choosing appropriate donors and acceptors [11, 12], and 2) to introduce electron-donating or electronwithdrawing atoms and groups, such as the Fatom, alcoxyl, cyano, rhodanine, etc. [13-17].

In this work, we have constructed eight phenanthrene- and eight phenanthroline-centered butterfly compounds and investigated the structural and electronic properties theoretically at the level of Density Functional Theory (DFT). These D- $\pi$-A type compounds may be potential candidates for organic solar cell applications, organic lightemitting diodes or fluorescent organic materials.

\section{METHOD OF CALCULATION}

The three-dimensional ground state $\left(\mathrm{S}_{0}\right)$ geometry of all compounds was geometry optimized using DFT [18] with the Gaussian 09W [19] package program and the hybrid functional B3LYP. B3LYP is composed of Becke's three parameter exchange functional (B3) [20] and the nonlocal correlation functional by Lee, Yang, and Parr (LYP) [21]. The basis set used for all atoms was 6$31++\mathrm{G}(\mathrm{d}, \mathrm{p})$ in both the DFT and time-dependent density functional theory (TD-DFT) methods.

For each compound, vibrational analyses were carried out using the same basis set employed in the corresponding geometry optimizations. The frequency analysis of none of the compounds yielded any imaginary frequencies, indicating that the structure of each molecule corresponds to at least a local minimum on the potential energy surface. The normal mode analysis was performed for $3 \mathrm{~N}-6$ vibrational degrees of freedom, with $\mathrm{N}$ being the number of atoms in the molecule.

The low-lying triplet (T) and singlet excited states (S) of the compounds were relaxed to obtain their minimum energy geometries using the TDDFT. The vertical excitation energies and oscillator strengths were obtained for the lowest triplet and singlet transitions at the optimized ground state equilibrium geometries by using TD-DFT with the same hybrid functional and basis set [22]. Optimized ground state structures were utilized to obtain the electronic absorption spectra, including maximum absorption wavelengths, oscillator strengths, and main configuration assignment by using TD-DFT. 


\section{RESULTS AND DISCUSSION}

The demand for economically viable for large-scale power generation based on environmentally green materials with limitless availability and variety has forced people to search for novel ideas and applications. Organic semiconductor materials are a cheaper alternative to inorganic counterparts like $\mathrm{Si}$. Organic photovoltaics can have extremely high optical absorption coefficients which provide potential for the production of very thin solar cells; therefore, they can be fabricated as thin flexible devices.

\subsection{Semiconductor properties}

The electronic structure of all organic semiconductors is based on the conjugation of $\pi$ electrons. A conjugated organic system consists of alternating between single and double carboncarbon bonds. Single bonds are known as $\sigma$-bonds and are associated with localized electrons, while double bonds are composed of a $\sigma$-bond and a $\pi$ bond. The $\pi$-electrons are mobile and can jump between carbon atoms due to the mutual overlap of $\mathrm{p}$ orbitals along the conjugation path, which causes the wave functions to delocalize over the conjugated skeleton. The empty $\pi$-bands are called the Lowest Unoccupied Molecular Orbital (LUMO) and $\pi$-bands filled with electrons are called the Highest Occupied Molecular Orbital (HOMO). The band gap $(\Delta \varepsilon)$ of semiconductor materials ranges from 1 to $4 \mathrm{eV}$.

Rigid polyaromatic planar carbon or heterocyclic compounds with donor- $\pi$-acceptor architecture have attracted much attention in recent years due to their special electro-optical properties originating from their low band gap [23, 24]. Phenanthrene is a polycyclic aromatic hydrocarbon composed of three fused benzene rings. The name phenanthrene is a composite of phenyl and anthracene. Phenanthrene is formed as a white powder with blue fluorescence. The compound with a phenanthrene skeleton and nitrogens at the 1 and 10 positions is known as 1,10-phenanthroline (Fig. 1).

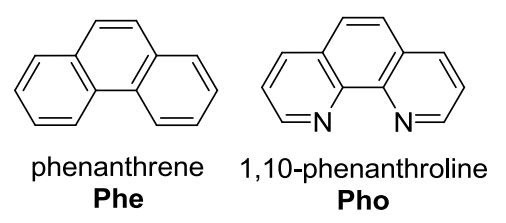

Fig. 1. Structures of phenanthrene (Phe) and 1,10-phenanthroline (Pho)
Phenanthrene has a curved structure and is more stable than its linear isomer, anthracene [25]. If phenanthrene is used as a donating backbone of the resulting conjugated structure, there is a chance of achieving high $\mathrm{V}_{\text {oc }}$ due to the high oxidation potential in comparison with thiophene derivatives resulting from their polyaromatic structures [26, 27]. In addition, phenanthrene units can show reasonable charge carrier mobility thanks to their potential to form strong $\mathrm{p}$-p stacking by virtue of their rigid and planar structure. However, it has been reported in the literature that the optical energy band gaps of its homopolymers are as large as about $3 \mathrm{eV}$ which results in a scarcity of light absorption, causing a reduced short circuit current $\left(\mathrm{J}_{\mathrm{sc}}\right)$ value in organic solar cells $[26,27]$. Thus, phenanthrene should be combined with strong acceptor unit in order to reduce the optical band gap of phenanthrene-based D-A type organic semiconductors.

Phenanthroline is a heterocyclic polyaromatic organic compound with a white solid character which is soluble in organic solvents. It is used as a ligand in coordination chemistry, as it forms strong complexes with most metal ions [28]. In addition, 1,10-phenanthroline is often chosen as a nitrogen ancillary ligand because it is a bidentate chelating ligand with strong steric hindrance, which can enhance the luminescence quantum yields of its complexes [28-31].

In the present research, eight phenantherene and eight phenanthroline based structures were studied computationally at B3LYP/6-31++G(d,p) level of theory. These highly conjugated systems are important in terms of their structural and electronic properties. They may be strong candidates for organic semiconductors and their potential applications as organic solar cells. The structures are designed in the form of D- $\pi$-A type organic systems (Fig. 2). The geometry optimized ground state structures of the compounds are shown in Figure 3.

In phenanthrene (Phe)-based systems, the Phe unit acts as the donor and strong electron withdrawing cyanides form the acceptor moiety. In addition, a $\pi$ system links the donor and acceptor in the structure. As a whole, the compounds possess high electron conjugation. For all of the compounds, the donor remained unchanged, as Phe, whereas the acceptor and $\pi$ system were altered to investigate the effect on the electronic structure. In compound Phe_8, the number of cyanides was doubled compared to the other derivatives. 


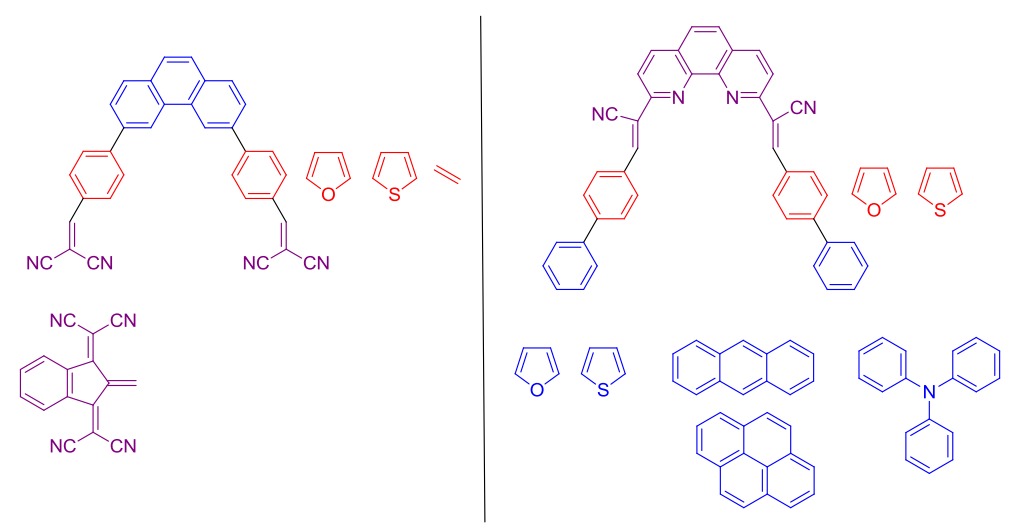

Fig. 2. General formula of the structures (blue: donor, red: $\pi$, violet: acceptor)

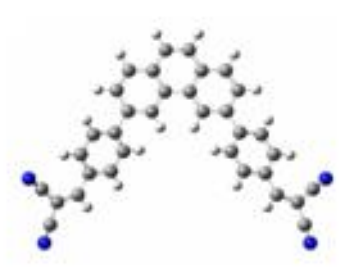

Phe_1

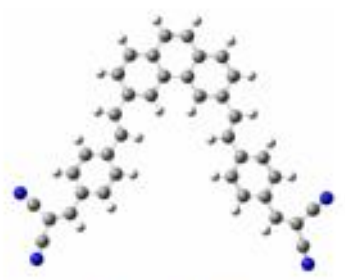

Phe 5

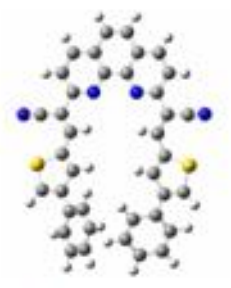

Pho_1

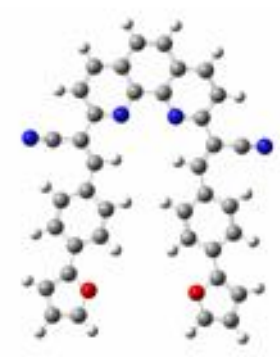

Pho 5

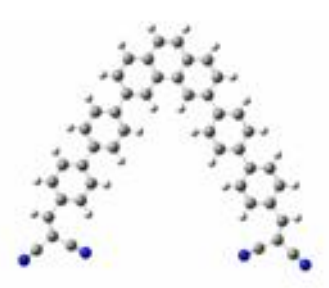

Phe_2

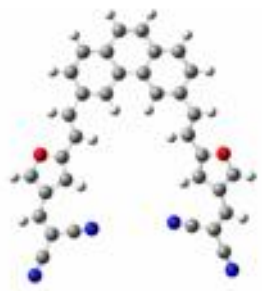

Phe_6

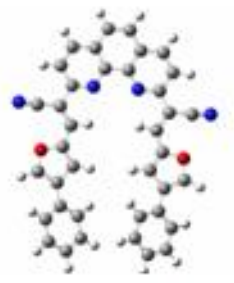

Pho_2

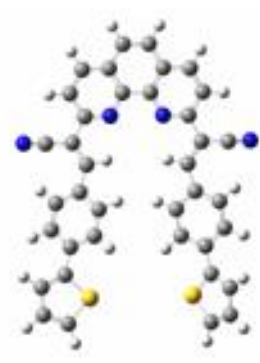

Pho_6

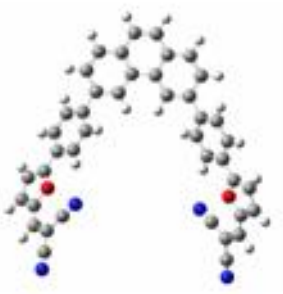

Phe_3

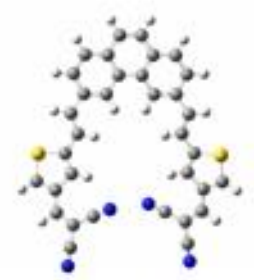

Phe_7

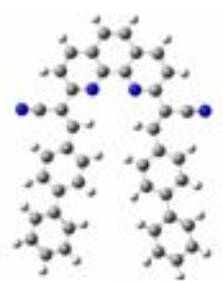

Pho_3

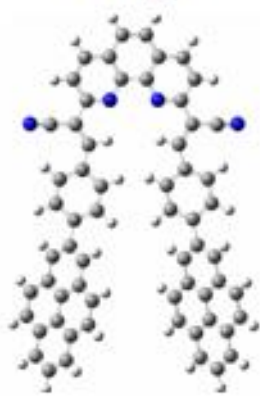

Pho_7

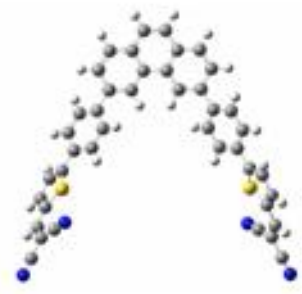

Phe_4

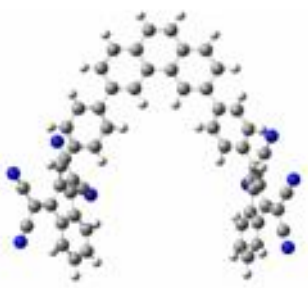

Phe_8

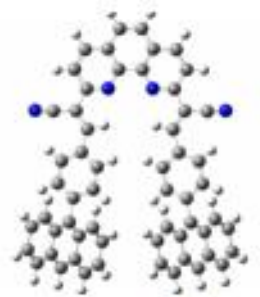

Pho_4

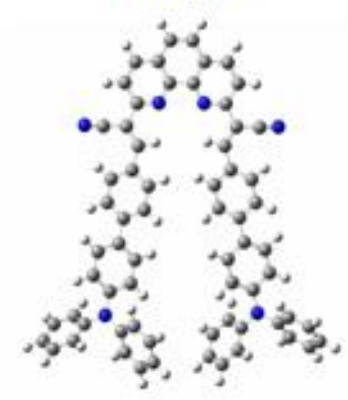

Pho_8

Fig. 3. Geometry optimized structures of Phe and Pho derivatives 
Phenanthroline (Pho), linked with one cyanide containing a double bond at either position 2 or 9 of the phenanthroline, is the acceptor part of the Pho-based compounds. Benzene, thiophene, and furan were used as the $\pi$ linkage. Donor units of benzene, thiophene, furan, anthracene, pyrene and triphenylamine were chosen. Extended conjugation was achieved for all compounds; however, acceptor units had to tilt from planarity due to steric hindrance in some cases (Fig. 3).

The inter-frontier molecular orbital energy gap $(\Delta \varepsilon)$ provides information about the conductivity of the system. According to the literature data, $\Delta \varepsilon \leq 0.1 \mathrm{eV}$ conductors, $\Delta \varepsilon=0.5-3.5 \mathrm{eV}$ semiconductors and $\Delta \varepsilon \geq 4.0 \mathrm{eV}$ insulator [32]. The interfrontier molecular orbital energy gaps $(\Delta \varepsilon)$ for all complexes are listed in Table 1.

Table 1

$H O M O, L U M O, \Delta \varepsilon$ and $\Delta \varepsilon_{S T}$ energies for the compounds in $\mathrm{eV}$

\begin{tabular}{cccccc}
\hline \hline Entry & HOMO & LUMO & $\Delta \mathcal{E}$ & $\Delta \boldsymbol{E}_{\text {ST }}{ }^{\text {a }}$ & $\Delta_{\text {ST }}{ }^{\text {b }}$ \\
\hline Phe & -5.75 & -1.01 & 4.74 & 1.28 & \\
Phe_1 & -6.22 & -3.11 & 3.11 & 0.72 & \\
Phe_2 & -5.82 & -2.88 & 2.94 & 0.52 & 0.61 \\
Phe_3 & -5.70 & -2.85 & 2.85 & 0.86 & \\
Phe_4 & -5.87 & -3.01 & 2.85 & 0.82 & \\
Phe_5 & -5.89 & -3.18 & 2.70 & 0.73 & \\
Phe_6 & -5.64 & -2.65 & 2.99 & 0.73 & \\
Phe_7 & -5.63 & -2.69 & 2.94 & 0.77 & \\
Phe_8 & -6.08 & -3.56 & 2.52 & 0.42 & 0.47 \\
Pho & -6.26 & -1.43 & 4.83 & 1.20 & \\
Pho_1 & -5.73 & -2.59 & 3.14 & 0.95 & \\
Pho_2 & -5.68 & -2.54 & 3.14 & 0.97 & \\
Pho_3 & -5.79 & -2.57 & 3.23 & 0.86 & \\
Pho_4 & -5.31 & -2.56 & 2.74 & 0.62 & 0.67 \\
Pho_5 & -5.53 & -2.54 & 3.00 & 0.80 & \\
Pho_6 & -5.65 & -2.60 & 3.05 & 0.81 & \\
Pho_7 & -5.52 & -2.55 & 2.96 & 0.75 & \\
Pho_8 & -5.08 & -2.47 & 2.61 & 0.36 & 0.41 \\
\hline \hline
\end{tabular}

${ }^{\mathrm{a} B}$ BLYP/6-31++G(d,p),

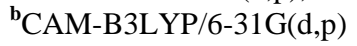

As stated before, the combination of donor units with acceptors is expected to reduce the interfrontier molecular orbital energy gap of a compound due to extension of the conjugation path. The HOMO and LUMO energies of phenanthrene were calculated at the same quantum-chemical computational level to be $-5.75 \mathrm{eV}$ and $1.01 \mathrm{eV}$, respectively, which resulted in a gap $(\Delta \varepsilon)$ of 4.74 $\mathrm{eV}$. The data were computed to be $-6.26 \mathrm{eV}$ and $1.43 \mathrm{eV}(\Delta \varepsilon=4.83 \mathrm{eV})$ for phenanthroline (Table
1). The computations showed that the energy values for the inter-frontier energy gap of both Phe and Pho fall into the category of insulators. The introduction of strong electron-withdrawing cyanide acceptor units and the $\pi$ linkages resulted in extension of the conjugation of $\pi$-electrons. This led to lowering of the LUMO energy levels for all of the systems, while the HOMO energies remained almost the same. Therefore, the HOMOLUMO band gap was narrowed and the resulting compounds became semiconductors. In the cases of Phe_8 and Pho_8, $\Delta \varepsilon$ values of $2.52 \mathrm{eV}$ and $2.61 \mathrm{eV}$ were obtained, respectively. The energies of the inter-frontier molecular orbital energy gaps vary between $2.52 \mathrm{eV}$ and $3.23 \mathrm{eV}$ for all compounds.

The 3D-frontier molecular orbital energy schemes are given in Figure 4 (Phe-based) and Figure 5 (Pho-based). The schemes for HOMO and LUMO give information about the reactivity of the compounds. HOMO provides basicity, while LUMO shows the Lewis acidity property of the corresponding system. Thus, investigation into frontier molecular orbitals is very important. It is also important to know which atoms contribute to these orbitals because the reactivity centers are determined by these schemes. For the compounds to be potential candidates for TADF, it is critical to possess separate HOMO and LUMO to give small exchange energies. Steric hindrance which results in twisting between donor and acceptor units can successfully achieve this purpose [33-35]. The HOMOs of Phe-based structures are predominantly distributed on the phenanthrene moiety (Fig. 4), whereas the LUMOs are localized over the acceptor core, and are composed of highly electronwithdrawing cyano units. This offers clear spatial separation of the HOMO and LUMO because of the large dihedral angles (ca. 30-40 ${ }^{\circ}$ ) between the phenanthrene moiety and the cyano-containing core. As for the Pho-based compounds (Fig. 5), good separation of the HOMO-LUMO could not be achieved due to an unbroken conjugation path, with anthracene (Pho_4), pyrene (Pho_7) and triphenylamine (Pho_8) donor units bearing derivatives being the exceptions. The HOMO and LUMO orbitals are distributed clearly on the donor and acceptor parts of the system, respectively. The sterically-hindered anthracene substituent tilted approximately $75^{\circ}$ and the remaining two around $40^{\circ}$ from the main plane. The narrowest band gaps were also observed for this trio. However, the planarity throughout the molecule is not that distorted for molecules containing benzene, thiophene and furan as donors. 

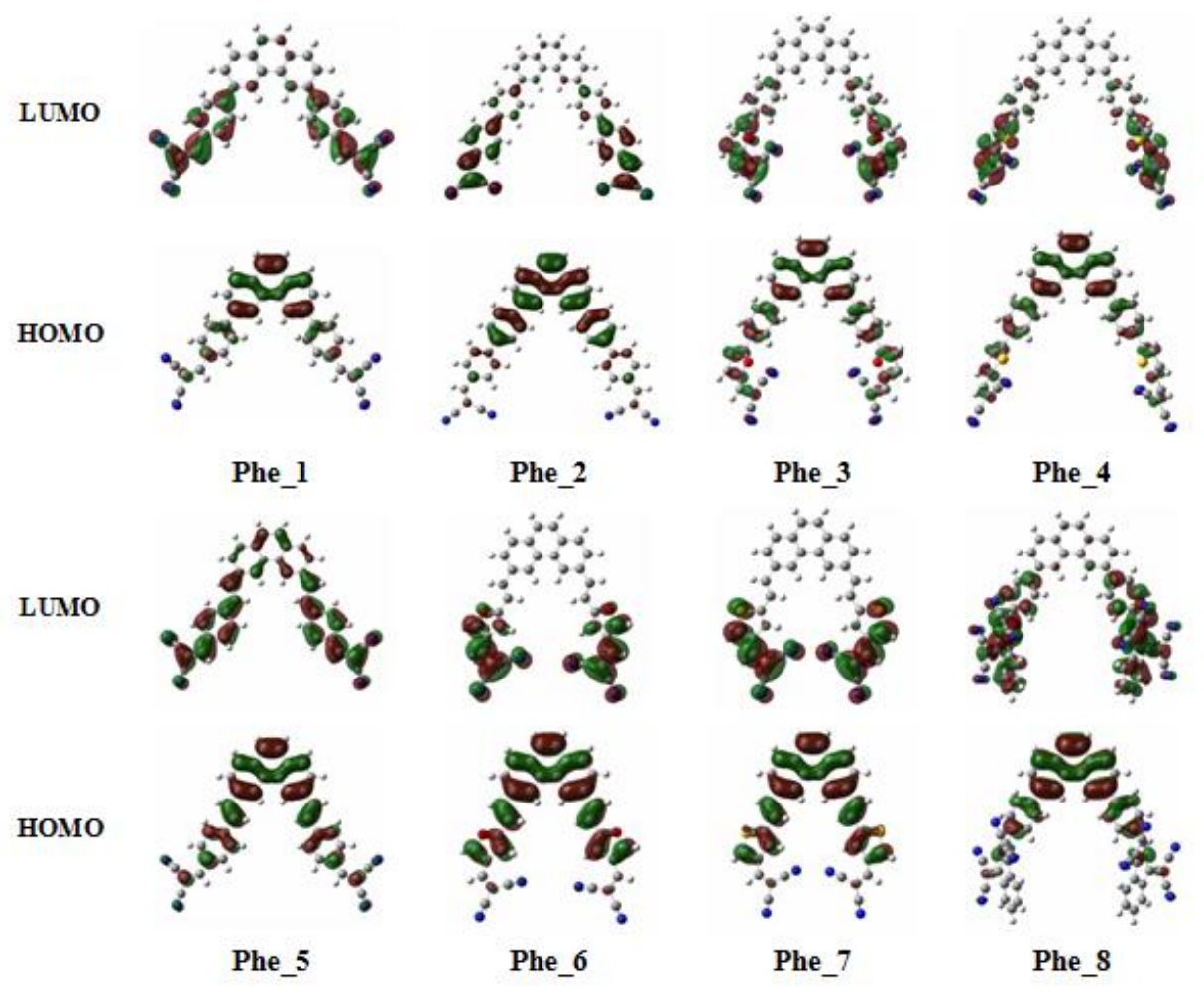

Fig. 4. HOMO and LUMO orbital schemes of Phe derivatives
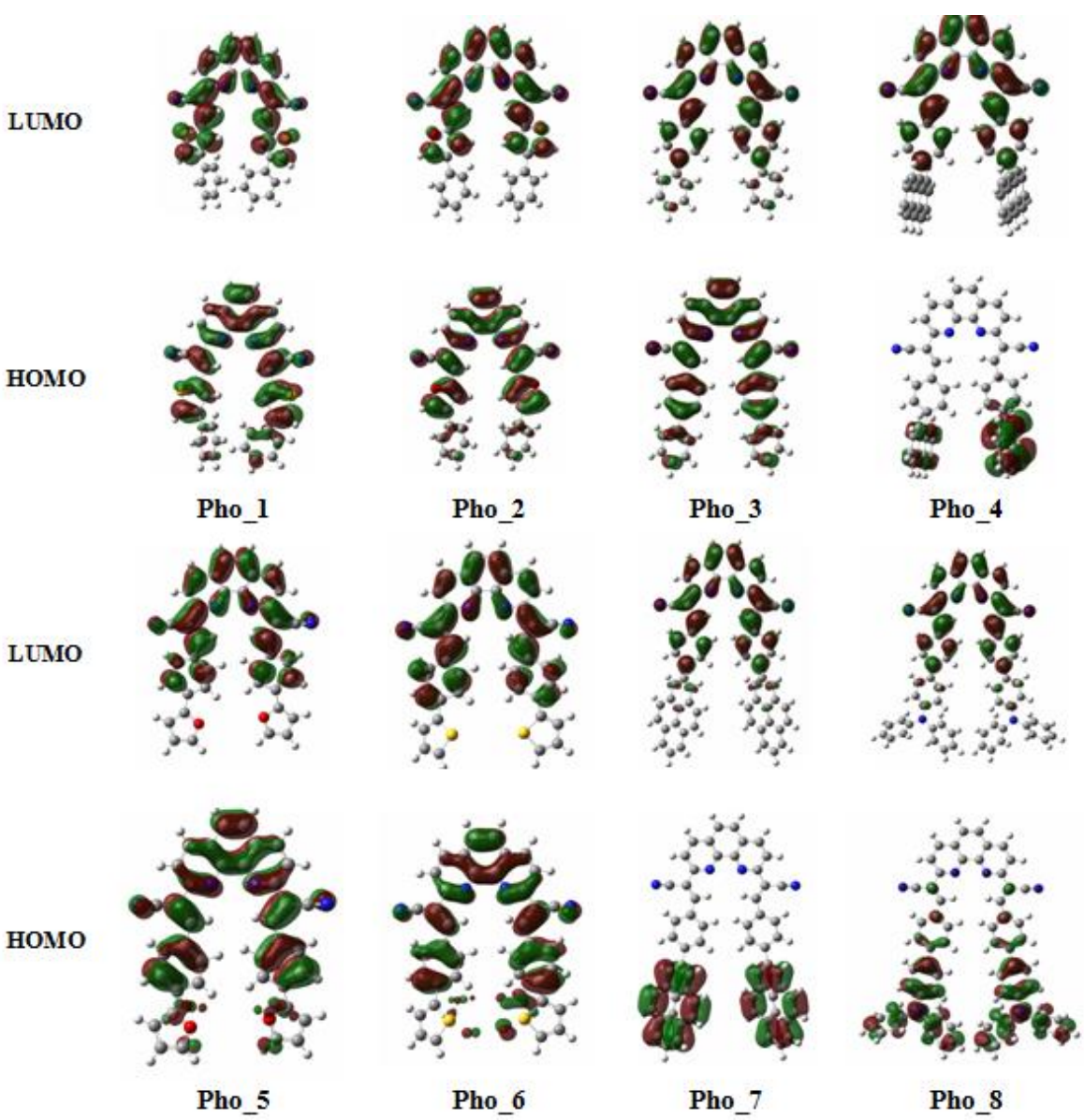

Fig. 5. HOMO and LUMO orbital schemes of Pho derivatives 


\subsection{TADF properties}

One of the most important design considerations of TADF molecules is obtaining a small energy gap between the $S_{1}$ and $T_{1}$ states $\left(\Delta \varepsilon_{\mathrm{ST}}\right)$. A molecule meets this requirement only when its lowest-energy transition has low singlet-triplet exchange energy [36]. Current trends in the research into novel TADF emitters are mainly focused on intramolecular donoracceptor (D-A)-type molecules, as in the present case [37]. Therefore, appropriate donor-acceptor units have to be selected carefully to obtain full-color TADF molecules, with their HOMO and LUMO being localized on different constituents. To obtain details about the geometric and electronic structures of Phe_1-Phe_8 and Pho_1-Pho_8, time-dependent density functional theory (TD-DFT) calculations were performed at the B3LYP/6-31++G(d,p) level. The HOMO, LUMO energies and the energy gap between singlet- and triplet-excited states for compounds Phe_1-Phe_8 and Pho_1-Pho_8 are given in Table 1.

The clear separation of the frontier molecular orbitals results in narrower $\Delta \varepsilon_{\mathrm{ST}}$ values. $\Delta \varepsilon_{\mathrm{ST}}$ data for Phe itself was reduced from $1.28 \mathrm{eV}$ to $0.52 \mathrm{eV}$ for Phe_2 and $0.42 \mathrm{eV}$ for Phe_8. On the other hand, Pho_4 and Pho_8 have been computed to have $\Delta \varepsilon_{\mathrm{ST}}$ of $0.62 \mathrm{eV}$ and $0.36 \mathrm{eV}$, respectively. Thus, the $\Delta \varepsilon_{\mathrm{ST}}$ values predicted by the TD-DFT calculations are small enough for thermal repopulation of the $S_{1}$ state via $T_{1} \rightarrow S_{1}$ reverse intersystem crossing (ISC) for all of the compounds, but especially for Phe_2, Phe_8, Pho_4 and Pho_8. Among all, Phe_8 and Pho_8 might suggest the highest potential as TADF emitters as they possess the narrowest $S_{1}-T_{1}$ energy difference and best separated HOMO and LUMO schemes. All computed lowest-energy excited states may be described by the HOMO-LUMO transition, which corresponds to an intramolecular charge transfer (ICT) with small exchange energy.

\subsection{NLO properties}

Nonlinear Optic (NLO) effects emerge from the interactions of electromagnetic fields in various media to generate new fields changed in phase, frequency, amplitude or other diffusion characteristics from the incident fields [38]. NLO materials have been widely investigated by researchers recently due to their importance in applicability as the key functions of frequency shifting, optical logic, optical switching, optical modulation and optical memory for the upcoming technologies in areas of telecommunications, signaling and optical interconnections [39-42].
A Taylor series expansion of the total dipole moment, $\mu_{\text {tot }}$, (Eq. 1) induced by the field represents the NLO response of an isolated molecule in an electric field $\mathrm{E}_{\mathrm{i}}(\omega)$ :

$$
\mu_{\mathrm{tot}}=\mu_{0}+\alpha_{\mathrm{ij}} \mathrm{E}_{\mathrm{j}}+\beta_{\mathrm{ijk}} \mathrm{E}_{\mathrm{jk}}+\ldots
$$

where $\alpha, \mu_{0}$ and $\beta_{\mathrm{ijk}}$ are linear polarizability, the permanent dipole moment and the first hyperpolarizability tensor, respectively. The isotropic (or average) linear polarizability can be calculated by equation (2) [43]:

$$
\alpha_{\mathrm{tot}}=\left(\alpha_{\mathrm{xx}}+\alpha_{\mathrm{yy}}+\alpha_{\mathrm{zz}}\right) / 3
$$

First hyperpolarizability is a third degree tensor that is represented by $3 \times 3 \times 3$ matrix. The 27 elements of the 3D matrix can be reduced to $10 \mathrm{com}$ ponents due to the Kleinman symmetry [43] such that $\beta_{\mathrm{xyy}}=\beta_{\mathrm{yxy}}=\beta_{\mathrm{yyx}}=\beta_{\mathrm{yyz}}=\beta_{\mathrm{yzy}}=\beta_{\mathrm{zyy}} ; \ldots$..). The output file of a computation in Gaussian 09 provides 10 values of this matrix as $\beta_{\mathrm{xxx}}, \beta_{\mathrm{xxy}}, \beta_{\mathrm{xyy}}, \beta_{\mathrm{yyy}}, \beta_{\mathrm{xxz}}, \beta_{\mathrm{xyz}}, \beta_{\mathrm{yyz}}$, $\beta_{\mathrm{xzz}}, \beta_{\mathrm{yzz}}$ and $\beta_{\mathrm{zzz}}$, respectively. The components of the first hyperpolarizability can be calculated using the following equation (Eq. 3) [44]:

$$
\beta_{\mathrm{i}}=\beta_{\mathrm{iii}}+1 / 3 \Sigma\left(\beta_{\mathrm{ijj}}+\beta_{\mathrm{jij}}+\beta_{\mathrm{jij}}\right)
$$

The magnitude of $\beta_{\text {tot }}$ from Gaussian program output can be calculated by Eq. 4 :

$$
\begin{gathered}
\beta_{\mathrm{tot}}=\left[\left(\beta_{\mathrm{xxx}}+\beta_{\mathrm{xyy}}+\beta_{\mathrm{xzz}}\right)^{2}+\left(\beta_{\mathrm{yyy}}+\beta_{\mathrm{yzz}}+\beta_{\mathrm{yxx}}\right)^{2}\right. \\
\left.+\left(\beta_{\mathrm{zzz}}+\beta_{\mathrm{zxx}}+\beta_{\mathrm{zyy}}\right)^{2}\right]^{1 / 2}
\end{gathered}
$$

The calculations of the total molecular dipole moment $\left(\mu_{\mathrm{tot}}\right)$, linear polarizability $\left(\alpha_{\mathrm{tot}}\right)$ and hyperpolarizability $\left(\beta_{\mathrm{tot}}\right)$ from the Gaussian output were explained in a previous work [45], and DFT has been widely used as an effective method to compute the properties of NLO materials [46]. The electronic dipole moment $\mu_{\text {tot }}$, polarizability $\alpha_{\text {tot }}$ and the hyperpolarizability $\beta_{\text {tot }}$ data of all compounds were calculated at the B3LYP/6$31++\mathrm{G}(\mathrm{d}, \mathrm{p})$ level of theory using the Gaussian 09 package; results are given in Table 2 .

The calculated dipole moments vary between 0.0 (Phe) and 15.6 (Phe_2) Debye for the Phe series. Phe itself is a nonpolar aromatic system; thus, observation of a zero dipole moment is not surprising. On the other hand, the charges are widely separated for Phe_2 so that the greatest magnitude of dipole moment was obtained for that compound. For the Pho series of molecules, Pho itself possessed a dipole moment of 3.2 D and the highest value was computed for Pho_8 as 4.0 D. 
The molecular electrostatic potential (MEP) indicates the electronic density and is quite a useful descriptor in locating sites for electrophilic attack and nucleophilic reactions as well as hydrogen bonding interactions $[47,48]$. Moreover, the dipole moment of the system can be well observed by the indication of charge separation via coloring. Being a real physical property, MEP can be determined experimentally by diffraction or by computational methods [49].

The 3D-MEP surface counter maps were obtained for B3LYP/6-31++G(d,p)-optimized geometries to predict reactive sites for electrophilic and nucleophilic processes for the compounds and dipole moment observation. The electrostatic potential surfaces of Phe, Phe_2, Pho and Pho_8 are shown in Figure 6. Electrophilic reactivity regions (negative charge) are shown by red and yellow colors, while blue is an indicator of nucleophilic reactivity [49]. For both series of compounds, the negative charge is localized on the electron withdrawing cyanide regions, as expected. The charge separation is very well observed for Phe_2, which may be the reason for the highest magnitude dipole moment (Fig. 6).
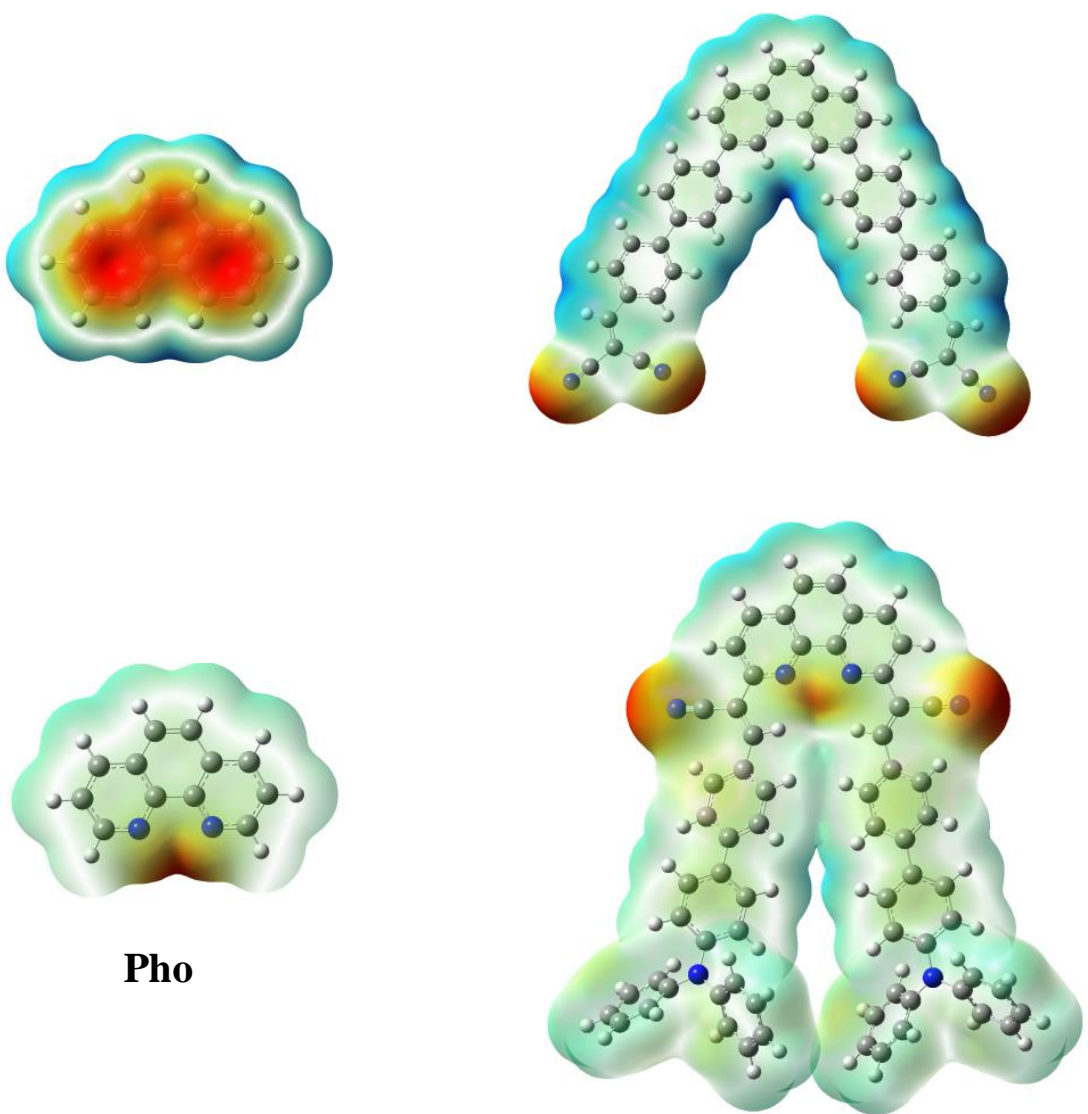

Pho_8

Fig. 6. Molecular electrostatic maps of Phe, Phe_2, Pho and Pho_8 computed at B3LYP/6-31++G(d,p) level of theory

The average polarizability $\left(\alpha_{\text {tot }}\right)$ data are also listed in Table 2. The highest values of calculated polarizabilities are equal to $214 \AA^{3}$ for Phe_7 and $230.8 \AA^{3}$ for Pho_6. Hyperpolarizability data $\beta_{\text {tot }}$ for all of the compounds are much greater than that of urea $\left(0.77 \times 10^{-30} \mathrm{~cm}^{5} / \mathrm{esu}\right)$ [50], which is one of the typical compounds used in research into the NLO properties of molecular systems. Therefore, it was used frequently as a threshold value for comparative studies [50]. The obtained results show that all of the compounds are good candidates of
NLO materials. Hyperpolarizability data for Phe and Pho were computed to be 0.2 and 0.8 ; thus, an increase in the conjugation path upon substitution of the $\pi$ link and other groups resulted in an increase in first hyperpolarizability. Comparison of inter-frontier energy gap data with the hyperpolarizability values is a good indicator of nonlinear properties. $\Delta \mathcal{E}$ for urea was calculated to be $8.2 \mathrm{eV}$ at the same level of DFT method, whereas the $\Delta \varepsilon$ values for the present systems vary in the range from 2.52 to $3.23 \mathrm{eV}$ (Table 1). 
T a ble 2

The calculated dipole moment $\mu_{\text {tot }}$ (Debye), the average polarizability $\alpha_{\text {tot }}\left(\AA^{3}\right)$ and first hyperpolarizability $\beta_{\text {tot }}\left(\times 10^{-30} \mathrm{~cm}^{5} / e s u\right)$ for the compounds

\begin{tabular}{cccc}
\hline \hline Entry & $\begin{array}{c}\text { Dipole } \\
\text { moment }\end{array}$ & $\begin{array}{c}\text { Average } \\
\text { polarizability }\end{array}$ & $\begin{array}{c}\text { First } \\
\text { Hyperpolariz- } \\
\text { ability }\end{array}$ \\
\hline Phe & 0.0 & 109.8 & 0.2 \\
Phe_1 & 9.3 & 130.0 & 91.1 \\
Phe_2 & 15.6 & 151.5 & 207.0 \\
Phe_3 & 9.9 & 162.6 & 120.7 \\
Phe_4 & 13.2 & 139.7 & 154.6 \\
Phe_5 & 10.5 & 117.5 & 197.4 \\
Phe_6 & 11.9 & 123.9 & 28.1 \\
Phe_7 & 10.4 & 214.0 & 40.5 \\
Phe_8 & 1.0 & 125.9 & 248.6 \\
Pho & 3.2 & 120.1 & 0.8 \\
Pho_1 & 1.2 & 133.7 & 32.7 \\
Pho_2 & 2.2 & 189.1 & 48.9 \\
Pho_3 & 1.2 & 135.1 & 72.4 \\
Pho_4 & 0.5 & 139.6 & 56.9 \\
Pho_5 & 2.7 & 228.6 & 144.2 \\
Pho_6 & 1.7 & 230.8 & 116.3 \\
Pho_7 & 2.2 & 33.0 & 159.4 \\
Pho_8 & 4.0 & 31.4 & 534.2 \\
\hline \hline
\end{tabular}

As can be seen from the $\Delta \varepsilon$ (Table 1) and $\beta_{\text {tot }}$ (Table 2) values for the present compounds, there is an inverse relationship between HOMOLUMO gap and first hyperpolarizability. In these systems, the molecular orbitals overlap to form a proper electronic conjugation, which is a marker of the intramolecular charge transfer from the electron-donating group through the $\pi$-conjugation system to the electron-withdrawing cyano group [51].

\section{CONCLUSION}

In the present study, we performed a computational study by applying Density Functional Theory at the B3LYP/6-31++G(d,p) level to sixteen compounds, eight of which are derivatives of phenanthrene, and the rest of which are phenanthroline derivatives.

The structures were constructed as a D- $\pi$-A motif in order to increase the ability to achieve intramolecular charge transfer, meaning that they may act as potential solar cell organic semiconductors. The inter-frontier energy gap of all of the compounds was obtained from DFT calculations and Phe_8 and Pho_8, with $\Delta \varepsilon$ values of $2.52 \mathrm{eV}$ and $2.61 \mathrm{eV}$, respectively, were found to possess the narrowest gaps. Thermally activated delayed fluorescence (TADF) properties of the compounds were discussed based on the results obtained by TDDFT calculations. Two critical points for potential TADF structures are: (i) separate distribution HOMO and LUMO orbitals throughout the molecule for small exchange energy and (ii) a narrow energy gap between the $S_{1}$ and $T_{1}$ states $\left(\Delta \varepsilon_{\mathrm{ST}}\right)$. The smallest $\Delta \varepsilon_{\mathrm{ST}}$ data were computed for Phe_2 and Phe_8 in the phenanthrene series, and Pho_4 and Pho_8 in the phenanthroline series. Thus, they may be considered for future TADF applications.

Moreover, nonlinear optic characteristics of all compounds were investigated through calculations of the total molecular dipole moment $\left(\mu_{\text {tot }}\right)$, linear polarizability $\left(\alpha_{\text {tot }}\right)$ and hyperpolarizability $\left(\beta_{\text {tot }}\right)$. The dipole moment data were supported by the computed molecular electrostatic potential maps. The hyperpolarizability values together with HOMO and LUMO energies of the compounds were compared with urea. The results indicated the potential nonlinear optic property of all of the systems.

\section{REFERENCES}

[1] A. S. Bagher, Introduction to Organic Solar Cells, Sustainable Energy 2, 85-90 (2014).

[2] H. Spanggaard, F. C. Krebs, A brief history of the development of organic and polymeric photovoltaic's, Sol. Energy Mater. Sol. Cells 83, 125-146 (2004).

[3] C. Brabec, V. Dyakanov, J. Parisi, N. S Sariciftci, Organic Photovoltaics: Concepts and Realization, Springer, New York, 2003.

[4] H. Hoppe, N. S. Sariciftci, Organic solar cells: an overview, J. Mater. Res. 19, 1924-1945 (2004).

[5] G. Li, V. Shrotriya, J. Huang, Y. Yao, T. Moriarty, K. Emery, Y. Yang, Nature Mater. 4, 864-868 (2005).

[6] H. N. Kim, Z. Q. Guo, W. H. Zhu, J. Y. Yoon, H. Tian, Recent progress on polymer-based fluorescent and colorimetric chemosensors, Chem. Soc. Rev. 40, 79-93 (2011).

[7] N. S. Sariciftci, L. Smilowitz, A. J. Heeger, F. Wudl, Photo induced electron transfer from a conducting polymer to buckminsterfullerene, Science 258, 14741476 (1992).

[8] Y. Lin, Q. He, F. Zhao, L. Huo, J. Mai, X. Lu, C. J. Su, T. Li, J. Wang, J. Zhu, Y. Sun, C. Wang, X. Zhan, A facile planar fused-ring electron acceptor for as-cast polymer solar cells with $8.71 \%$ efficiency, J. Am. Chem. Soc. 138, 2973-2976 (2016).

[9] S. H. Liao, H. J. Jhuo, Y. S. Cheng, S. A. Chen, Fullerene derivative-doped zinc oxide nanofilm as the cathode of inverted polymer solar cells with lowbandgap polymer (PTB7-Th) for high performance, $A d v$. Mater. 25, 4766-4771 (2013). 
[10] M. C. Scharber, D. Mühlbacher, M. Koppe, P. Denk, C. Waldauf, A. J. Heeger, C. J. Brabec, Design rules for donors in bulk-heterojunction solar cells-towards $10 \%$ energy-conversion efficiency, Adv. Mater. 18, 789-794 (2006).

[11] J. A. Love, C. M. Proctor, J. Liu, C. J. Takacs, A. Sharenko, T. S. van der Poll, A. J. Heeger, G. C. Bazan, T.-Q. Nguyen, Film morphology of high efficiency solution-processed small-molecule solar cells, $A d v$. Funct. Mater. 23, 5019-5026 (2013).

[12] L. Liang, J.-T. Wang, X. Xiang, J. Ling, F.-G. Zhao, W.$\mathrm{S}$. Li, Influence of moiety sequence on the performance of small molecular photovoltaic materials, J. Mater. Chem. A 2, 15396-15405 (2014).

[13] B. Kan, Q. Zhang, M. Li, X. Wan, W. Ni, G. Long, Y. Wang, X. Yang, H. Feng, Y. Chen, Solution-processed organic solar cells based on dialkylthiol-substituted benzodithiophene unit with efficiency near $10 \%, \mathrm{~J}$. Am. Chem. Soc. 136, 15529-15532 (2014).

[14] B. Kan, M. Li, Q. Zhang, F. Liu, X. Wan, Y. Wang, W. Ni, G. Long, X. Yang, H. Feng, Y. Zuo, M. Zhang, F. Huang, Y. Cao, T. P. Russell, Y. Chen, A series of simple oligomer-like small molecules based on oligothiophenes for solution-processed solar cells with high efficiency, $J$. Am. Chem. Soc. 137, 3886-3893 (2015).

[15] T. L. Nguyen, H. Choi, S. J. Ko, M. A. Uddin, B. Walker, S. Yum, J. E. Jeong, M. H. Yun, T. J. Shin, S. Hwang, J. Y. Kim, H. Y. Woo, Semi-crystalline photovoltaic polymers with efficiency exceeding $9 \%$ in a 300 $\mathrm{nm}$ thick conventional single-cell device, Energy Environ. Sci. 7, 3040-3051 (2014).

[16] J. Lu, J. Peng, Y. Wang, J. Yuan, C. Sheng, H.-Q. Wang, W. Ma, Benzo[1,2-b:4,5-b0]dithiophene-fumaronitrile-based D-A type copolymers with different $\mathrm{p}$ bridges: synthesis, characterization and photovoltaic properties, Synth. Met. 188, 57-65 (2014).

[17] Z. Du, W. Chen, M. Qiu, Y. Chen, N. Wang, T. Wang, M. Sun, D. Yu, R. Yang, Utilizing alkoxyphenyl substituents for side-chain engineering of efficient benzo[1,2-b:4,5-b']dithiophene-based small molecule organic solar cells, Phys. Chem. Chem. Phys. 17, 1739117398 (2015).

[18] W. Kohn, L. J. Sham, Self-consistent equations including exchange and correlation effects. Phys. Rev. 140, 1133-1138 (1965).

[19] M. J. Frisch, G. W. Trucks, H. B. Schlegel, G. E. Scuseria, M. A. Robb, J. R. Cheeseman, G. Scalmani, V. Barone, B. Mennucci, G. A. Petersson, H. Nakatsuji, M. Caricato, X. Li, H. P. Hratchian, A. F. Izmaylov, J. Bloino, G. Zheng, J. L. Sonnenberg, M. Hada, M. Ehara, K. Toyota, R. Fukuda, J. Hasegawa, M. Ishida, T. Nakajima, Y. Honda, O. Kitao, H. Nakai, T. Vreven, J. A. Montgomery, Jr., J. E. Peralta, F. Ogliaro, M. Bearpark, J. J. Heyd, E. Brothers, K. N. Kudin, V. N. Staroverov, T. Keith, R. Kobayashi, J. Normand, K. Raghavachari, A. Rendell, J. C. Burant, S. S. Iyengar, J. Tomasi, M. Cossi, N. Rega, J. M. Millam, M. Klene, J. E. Knox, J. B. Cross, V. Bakken, C. Adamo, J. Jaramillo, R. Gomperts, R. E. Stratmann, O. Yazyev, A. J. Austin, R. Cammi, C. Pomelli, J. W. Ochterski, R. L. Martin, K. Morokuma, V. G. Zakrzewski, G. A. Voth, P. Salvador, J. J. Dannenberg, S. Dapprich, A. D. Daniels,
O. Farkas, J. B. Foresman, J. V. Ortiz, J. Cioslowski, and D. J. Fox, Gaussian 09, Revision D.01, Gaussian, Inc., Wallingford CT, 2013.

[20] A. D. Becke, Density-functional exchange-energy approximationwith correct asymptotic behavior. Phys. Rev. A 38, 3098-3100 (1988).

[21] C. Lee, W. Yang, R.G. Parr, Development of the ColleSalvetti correlation energy formula into a functional of the electron density. Phys. Rev. B 37, 785-789 (1988).

[22] M. E. Casida, C. Jamorski, K. C. Casida, D. R. Salahub, Molecular excitation energies to high-lying bound states from timedependent density-functional response theory: characterization and correction of the time-dependent local density approximation ionization threshold. $J$. Chem. Phys. 108, 4439-4449 (1998).

[23] J. A. Mikroyannidis, D. V. Tsagkournos, S. S. Sharma, Y. K. Vijay, G. D. Sharma, Low band gap conjugated small molecules containing benzobisthiadiazole and thienothiadiazole central units: synthesis and application for bulk heterojunction solar cells. J Mater Chem 21, 4679-4688 (2011).

[24] P. Sonar, S. P. Singh, Y. Li, M. S. Soh, A. Dodabalapur, A low-bandgap diketopyrrolopyrrole-benzothiadiazolebased copolymer for high-mobility ambipolar organic thin-film transistors. Adv Mater. 22, 5409-5413 (2010).

[25] H. Tian, J. Shi, S. Dong, D. Yan, L. Wang, Y. Geng, F. Wang, Novel highly stable semiconductors based on phenanthrene for organic field-effect transistors, Chem. Commun. 3498-3500 (2006).

[26] C. Yang, H. Scheiber, E. J. W. List, J. Jacob, K. Mu, Polyphenylene and poly(phenylenevinylene) analogues, Macromolecules 39, 5213-5221 (2006).

[27] B. N. Boden, K. J. Jardine, A. C. W. Leung, M. J. MacLachlan, Tetraalkoxyphenanthrene: a new precursor for luminescent conjugated polymers, Org. Lett. 8, 1855-1858 (2006).

[28] C. R. Luman, F. N. Castellano, Phenanthroline Ligands in Comprehensive Coordination Chemistry II, Elsevier, Pergamon, 2003.

[29] M. Correa-Ascencio, E. K. Galvan-Miranda, F. RascónCruz, O. Jiménez-Sandoval, S. J. Jiménez-Sandoval, R. Cea-Olivares, V. Jancik, R. A. Toscano, V. GarcíaMontalvo, Lanthanide(III) complexes with 4,5bis(diphenylphosphinoyl)-1,2,3-triazolate and the use of 1,10-phenanthroline as auxiliary ligand, Inorg. Chem. 49, 4109-4116 (2010).

[30] J. R. Zheng, N. Ren, J. J. Zhang, D. H. Zhang, L. Z. Yan, Y. Li, Crystal Structures and luminescent and thermal properties of lanthanide complexes with 3,5diisopropylsalicylic acid and 1,10-phenanthroline, $J$. Chem. Eng. Data 57, 2503-2510 (2012).

[31] S. H. Fan, A. G. Zhang, C. C. Ju, L. H. Gao, K. Z. Wang, A Triphenylamine-grafted imidazo[4,5-f] [1,10]phenanthroline ruthenium(II) complex: Acid-base and photoelectric properties, Inorg. Chem. 49, 3752-3763 (2010).

[32] W. D. Callister, Materials Science and Engineering-An Introduction, John Wiley and Sons, Inc. USA, 2007.

[33] T. Nakagawa, S. Y. Ku, K. T. Wong, C. Adachi, Electroluminescence based on thermally activated 
delayed fluorescence generated by a spirobifluorene donor-acceptor structure, Chem. Commun. 48, 95809582 (2012).

[34] G. Mehes, H. Nomura, Q. Zhang, T. Nakagawa, C. Adachi, Enhanced electroluminescence efficiency in a spiro-acridine derivative through thermally activated delayed fluorescence, Angew. Chem. Int. Ed. 51, 1131111315 (2012).

[35] K. Nasu, T. Nakagawa, H. Nomura, C. J. Lin, C. H. Cheng, M. R. Tseng, T. Yasuda, C. Adachi, A highly luminescent spiro-anthracenone-based organic lightemitting diode exhibiting thermally activated delayed fluorescence, Chem. Commun. 49, 10385-10387 (2013).

[36] N. J. Turro, Modern Molecular Photochemistry, University Science Books, 1991.

[37] J. Li, Q. Zhang, H. Nomura, H. Miyazaki, C. Adachi, Thermally activated delayed fluorescence from $n \pi *$ to $n \pi *$ up-conversion and its application to organic light- emitting diodes, Appl. Phys. Lett. 105, 013301-013304 (2014).

[38] T. Yanai, D. P. Tew, N. C. Handy, A new hybrid exchange-correlation functional using the Coulombattenuating method (CAM-B3LYP), Chem. Phys. Lett. 393, 51-57 (2004).

[39] Y. X. Sun, Q. L. Hao, W. X. Wei, Z. X. Yu, L. D. Lu, X. Wang, Y. S. Wang, Experimental and density functional studies on 4-(3,4-dihydroxybenzylideneamino)antipyrine, and 4-(2,3,4-trihydroxybenzylideneamino)antipyrine, $J$. Mol. Struct.:Theochem 904, 74-82 (2009).

[40] C. Andraud, T. Brotin, C. Garcia, F. Pelle, P. Goldner, B. Bigot, A. Collet, Theoretical and experimental investigations of the nonlinear optical properties of vanillin, polyenovanillin, and bisvanillin derivatives, $J$. Am. Chem. Soc. 116, 2094-2102 (1994).

[41] V. M. Geskin, C. Lambert, J. L. Bredas, Origin of high second- and third-order nonlinear optical response in ammonio/borato diphenylpolyene zwitterions: the remarkable role of polarized aromatic groups, J. Am. Chem. Soc. 125, 15651-15658 (2003).

[42] M. Nakano, H. Fujita, M. Takahata, K. Yamaguchi, Theoretical study on second hyperpolarizabilities of phenylacetylene dendrimer: Toward an understanding of structure-property relation in NLO responses of fractal antenna dendrimers, J. Am. Chem. Soc. 124, 9648-9655 (2002).

[43] D. Sajan, H. Joe, V. S. Jayakumar, J. Zaleski, Structural and electronic contributions to hyperpolarizability in methyl phydroxy benzoate, J. Mol. Struct. 785, 43-53 (2006).

[44] R. Zhang, B. Du, G. Sun, Y. X. Sun, Experimental and theoretical studies on o-, $\mathrm{m}$ - and p-chlorobenzylideneaminoantipyrines, Spectrochim. Acta A 75, 1115-1124 (2010).

[45] D. A. Kleinman, Nonlinear dielectric polarization in optical media, Phys. Rev. 126, 1977-1979 (1962).

[46] K. S. Thanthiriwatte, K. M. Nalin de Silva, Non-linear optical properties of novel fluorenyl derivatives $-\mathrm{ab}$ initio quantum chemical calculations, J. Mol. Struct.:Theochem 617, 169-175 (2002).

[47] H. Tanak, K. Pawlus, M. K. Marchewka, A. Pietraszko, Structural, vibrational and theoretical studies of anilinium trichloroacetate: New hydrogen bonded molecular crystal with nonlinear optical properties, Spectrochim. Acta Part A, 118, 82-93 (2014).

[48] E. Scrocco, J. Tomasi, Topics in Current Chemistry, vol. 7, Springer, Berlin, 1973.

[49] F. J. Luque, J. M. Lopez, M. Orozco, Perspective on "Electrostatic interactions of a solute with a continuum. A direct utilization of $a b$ initio molecular potentials for the prevision of solvent effects", Theor. Chem. Acc. 103, 343-345 (2000).

[50] H. Tanak, A. A. Agar, O. Buyukgungor, Experimental (XRD, FT-IR and UV-Vis) and theoretical modeling studies of Schiff base (E)-N'-((5-nitrothiophen-2yl)methylene)-2-phenoxyaniline, Spectrochim. Acta Part $A$, 118, 672-682 (2014).

[51] H. Tanak, Density functional computational studies on 2[(2,4-Dimethylphenyl)iminomethyl]-3,5-dimethoxyphenol, Int. J. Quant. Chem. 112, 2392-2402 (2012).

[52] H. Tanak, Molecular structure, spectroscopic (FT-IR and UV-Vis) and DFT quantum-chemical studies on 2-[(2,4dimethylphenyl)iminomethyl]-6-methylphenol, Mol. Phys. 112, 1553-1565 (2014). 